\title{
INEㄴㄴㄴㅐ
}

ISSN-2321-7065

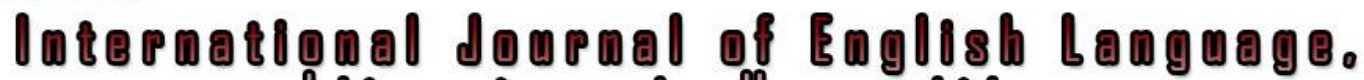

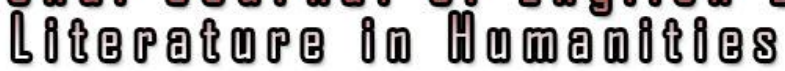

Indexed,Peer Reviewed (Refereed), UGC Approved Journal



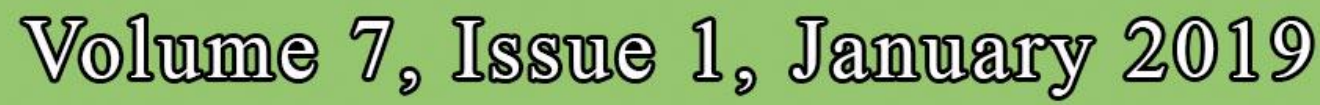


R. Ahalya

MPhil Scholar, Holy Cross College,

Manonmaniam Sundaranar University,

Arudesam village, Kanya Kumari district, Tamil Nadu, India.

Ahalya18031996@gmail.com

\section{Role of Nature in Michelle Cohen Corasanti's The Almond Tree}

Abstract: This paper entitled "Role of Nature in Michelle Cohen Corasanti's The Almond Tree" represents the relationship man has with nature and vice versa. It also explains that though The Almond Tree is a war novel, Corosanti brings in the tint of nature here and there in the novel. It also talks about certain ways through which nature can be retained and the double destruction on nature due to the man-made causes. The obliteration caused to man and to nature by war has been portrayed in this paper. It is the duty of every human being to look after the well being of nature. When one put in the effort to protect the nature, it naturally attracts others to protect the nature. Unless protecting the nature, it is the future generation which suffers the most than the present generation. In short, this paper stresses on the necessity of protecting the nature.

God, the creator of the whole world, creates nature as well as man. He then delivers the nature in the hands of man with a hope that man gives priority to protect his creation. Nature is a mother, nurturer, doctor, teacher and entertainer. It is filled with adventures, amusements, beauty and sometimes even danger. There is a balance within the ecosystem to enjoy the benefits of mutual co-existence. When this balance is maintained, there blooms peace and happiness. But if any one of it tries to dominate, there would be great tragedy. Nature is a best healer in every situations of human life. Though selfishness leads the man to destroy the nature, there are few people who are able to understand the importance of nature. There is a deep 
relationship between the man and nature. So, it is necessary to look at the relationship between the nature and the man in Corasanti's The Almond Tree.

The novel revolves around the plot of war, sufferings, melancholy and revenge. But even in such a serious situation Corasanti is able to concentrate on nature. This shows her interest in nature. When Ahmed, the protagonist is brought to the new house by the soldiers, the only thing which gives a bit of satisfaction to him is the almond tree which is there in front of the house. It acts as a food source to the family, helps in the improvement of the knowledge of Ahmed Hamid. The tree is considered as a playmate and it is personified as a girl and Ahmed gives her a name Shahida which means witness. He gives the name not only to the almond tree but also to the olive trees as Amal which means hope and Sa'dah which means happiness. On seeing this, Easterine Kire's novel When the River Sleeps comes into the mind. In this novel the tribal people address the fig tree as their brothers due to certain myth. This shows how these tribal people are one with the nature no matter whether they follow the myth or not. Like them, Ahmed Hamid also has a close relationship with trees. He considers nature to be a part of him. These days the major issue in this world is pollution. Air, water and land are polluted. Even the present generation finds it difficult to cope up with the situation. It is very pathetic while considering the situation of the future generations. Even today the metro cities find it a great difficulty to breathe the fresh air. They are in a situation to buy fresh air by paying money. The major reason for this is the increase in the number of factories.

Corasanti brings out this issue of man against nature through a slaughter house. Ahmed Hamid works in the slaughter house and he explains the pathetic condition of the village after the opening of the slaughter house. His village is situated in the top of the hill. And so, there are varieties of flowering plants and other trees. But now, due to the slaughter house, there are only filth and chemicals all over the village as there is no proper sewage system. In the land, bubbles of carbonic acid rises up to the surface and even the land catches fire every now and 
then as there is a layer of filth and chemicals in the ground. The people, as they have no other go, pour buckets of water to put off the fire. A single factory in the village spoils air, water and soil of the village. As the land is filled with filth and chemicals, there are many disadvantages and ailments. First, the rain water cannot penetrate into the soil so that the level of the underground water gets reduced. Secondly, even if the rain water penetrates into the soil and reaches the ground water level, it will not be pure. There will be mixture of the chemicals in the water. So, when it reaches the underground level, it becomes acidic that cannot be consumed. When this polluted water is consumed by the people it creates various mortal diseases such as cancer.

When there are a large number of trees planted in the village, there would be large amount of oxygen produced by the trees. This helps to overcome the problem of pollution to a limited extend. The cutting of a single tree is a great loss. Only by afforestation the problems can be solved.

The next issue seen in this novel that devastates nature is war. It is a cruel thing that affects the ecosystem. It takes away the lives of the people and it creates a situation in which the people cannot survive. When there is war, there would be a number of bomb blasts. These create smoke and which in turn pollutes the environment and the poisonous smoke kills a number of people by creating lung diseases. It destroys the life of many organisms and creates an imbalance in the ecosystem. This imbalance leads to various after effects taking decades to get out of it.

In this novel, people suffer due to lack of food, lack of education and suffer as they are unable to face even their basic needs. Now the nature around them is also destroyed. This acts as the basic reason for the sufferings of the people. In this novel Israelis try to suppress the Arabs and when there is war, there is attack on both sides. It is obvious that the stronger side wins. But they are not aware that the environment does not show any partiality on any one side. 
When the nature of the part of a country is affected, the whole country will be affected. So, both the Israelis and the Arabs have to face the consequences. In short, war swallows the pleasant nature. It is very difficult and necessary to attain normalcy.

Corasanti expresses the happiness one receives from the pleasant nature through Ahmed Hamid. She explains how the pleasant smell of the flowers reaches him when he walks through the hillside. "The flower scent reached me about half way up the hill" (34). She also explains the beauty of the nature to show its harmlessness unlike human beings. "Bougainvillea in shades of purple and fuchsia climbed the trellises ..." (35).This line shows how fertile the land is. Nature provides everything to human in abundance. But human beings are not ready to understand and act accordingly.

The people who live in Israel, especially, the Arabs cultivate oranges. Oranges of Gaza are the most popular and most loved ones among all other oranges. There is a special taste to the oranges of Gaza. Even Ahmed Hamid's family has owned an orange groove in the beginning. But now it is in the hands of the Jews. They are not ready to take care of the grooves as their owners once cared. This in turn leads to the destruction of these popular variety of oranges.

Nature is filled with medicinal plants. Whatever be the disease, there is medicine in the nature. Nature is filled with a number of surprises. Corasanti points out only a few medicinal plants. Similarly, Easterine Kire in her novel When the River Sleeps points out certain medicinal plants such as "Ciena which is a herb used to staunch blood from cuts, Tierhutiepfi is a curative herb, etc." (Kire 32). But the pathetic thing is due to the attraction towards the allopathic medicine, the people forget these herbs. The present generation is unable to distinguish the medicinal herbs from the weeds. There must be change in the mentality of the people. Everyone must learn about the natural herbs and can try to use it. 
Everyone can put on their own steps to plant trees. When one takes step in planting trees, slowly one by one everyone steps forward in planting trees. Corasanti shapes the protagonist in such a way that he is so very close to nature. He plants trees, protects them and he is so very happy in the growth of these trees. He feels as if he is relived out of his stress when he is with the trees. Most of his childhood is spent under the almond tree. Even at the end of the novel, as Nora is buried under the almond tree, he feels the presence of her there. He lives his whole life depending on nature.

For the survival of human beings, nature is essential. Without nature, the world cannot be dreamed of. If the natural resources get destroyed as now, it is sure that within few years the fertile land would become deserts. Though the beautiful nature is treated very badly without giving its own right to live, it is not too late to protect the nature.

Corasanti brings out the emotional wellness nature provides man, by expressing the internal joy of Baba when it rains, "he still rejoiced when it rained" (95). When the rain falls, he says that it is necessary for the land and the trees. It makes the barren land as a fertile land. It is one among the five elements. These five elements are the basis of the nature. Corasanti also talks about other elements like the power of fire which is terrific during war, of air which gets polluted and of land through its importance and water through rain. There are many things to learn about the nature and many things to learn from nature. Nature has more experience than man.

It is necessary to have knowledge about the relation nature has with us. The effects that occur due to the mistakes done by man against the nature due to his selfishness have to be realized. And everyone must voluntarily take steps to rectify the mistakes. Everyone must learn to observe nature deeply and to love nature to a great extent. So that, the human mind only think of the welfare of the surrounding. This leads to a perfect balance in the ecosystem. When there is balance in the ecosystem, the threats posed by nature on man and vice versa can be 
reduced. Earth must retain its own beauty and man must live one with nature without giving any importance to the artificial world. Let us take steps to tally the loss by planting the trees. If this occurs, then earth would become the Paradise where God loves to live. 
Works Cited

Corasanti, Michelle Cohen. The Almond Tree, Finger Print, 2013.

Kire, Easterine. When the River Sleeps, Zubaan Publishers Pvt. Ltd, 2014. 